\title{
The Influences of Blended Learning with WhatsApp Android Application to Students Responses in Medan State University
}

\author{
Muhammad Badzlan Darari ${ }^{1}$ and Suci Frisnoiry ${ }^{2}$ \\ Department of Mathematics Education, Medan State University, North Sumatera, \\ Indonesia $^{1,2}$ \\ \{badzlan@unimed.ac.id,\}
}

\begin{abstract}
This study revealed the students' responses in blended learning with WhatsApp android application. This study was held in Class B year 2016 Mathematics Education Department Medan State University. Subjects of this research were 39 students divided into six groups in the course of Research Method. The research applied qualitative method with descriptive design. Result of this study showed positive responses from students during the learning process. They could learn everywhere utilizing internet network by their smartphone. Learning makes students more energetic and more flexible, so it raises their comfort which influences their responses.
\end{abstract}

Keywords: Blended learning, WhatsApp Application, Students' respond.

\section{Introduction}

Research method is one of the courses in Department of Mathematics Education, Medan State University. This course supplies knowledge and technique about how to do research in students' thesis. The sucsess of this course can not be seen directly from the students' grades of the course, but it can be seen frow how fast the students compile a research proposal and quality of their research report.

Based on Accreditation Report issued by Department of Mathematics Education, from 2010 to 2014 only 58,6\% students completed their studies in four years. Students having dificulties in prepared research proposal. Author interviewed 10 fifth-year students who cunduct proposal seminar in Department of Mathematics Education. The results of the interview explained that students need a long time in the thesis guidance process and make many times revisions. Then, the author interviewed 4 senior lecturer as the thesis supervisior. The results of the interview explained that the supervisor had conducted guidance according to the procedure, but the students still made the same mistake. A supervisor told, "They need 2 weeks just to determine problem of the research, then it takes a month or several times revisions just to compile background problem of the research in chapter one. Can you imagine how long they need to compile aproposal, conduct research, and write a thesis? More than eight months". The author conclud that the situation caused by students' low skill to compile 
the logic-narrative contents of the proposal research. Even though all studensts had passed course of Research Method in sixth semester.

Author re-conducted deep interview the students and obtained shocking resutls. The students got high score in course of Research Method, about grade A or B. However, after almost a year passed, at eighth semester they forgot all the lecturer explanations of the course. A student told, "Course of Research Method is different from the other course that contain theorems, formulas, and procedures, which when undertood once would be remembered. This course contains methods and technique in writing a proposal that we understood at the time, but now we forget. We might understimated this course". Then the author conducted that student's low skill to compile a proposal research caused by they responses to the course is low.

Respone is a reaction of a person to the stimulus (Skinner, 1996) and (Pierce and Stacy, 2001). Students' responses to the learning process depend on the learning model and approach used by the teacher (Lestari, 2014). Positive response will be maintained if the students feels the benefit of the stimulus and feels comfort in it. At the end, response can become a habit of the students. By the definition, author propose a new way to learn which utilized Information and Communication.

Technologies (ICT). Author attempted to used blended learning by using ICT as an effort to improve students' responses in the course of research method.

Basically, blended learning is a composite of on-line learning and face-to-face learning (Motlan, Sinulingga, Siagian, 2016). The approach may utilize a wide variety of media and technology. There are three advantages of using blended learning; (a) to improve learning activities, (b) to give flexible time and space, and (c) to reduce cost (Singh, 2003). The combination of learning between real classrooms and virtual classrooms can improve student morale and response (Gon and Rawekar, 2017). To optimize the design method of inquirybased blended learning requires the development of inquiry based teaching materials and blended learning along with other supporting devices. Blended learning can be done using ICT especially on smartphones through the internet network.

Now, due to the rapid increase in smartphone users and internet users, a new paradigm shift in learning from the e-learning phase to m-learning. There are many benefits such as access anytime and anywhere, facilitate collaboration, and reduce barriers between students and teachers (Mohammed, Laila, and Hamza, 2012). WhatsApp is one of the instant messenger application in social networking that provide by android on smart phone. Usage of WhatsApp messenger made communication through mobile phones has become easier, faster and cheaper (Yeboah and Ewur, 2014). This application is in great demand for several reasons; freely available, simple messaging, able to share text, images and videos, and used as discussion forum. WhatsApp is the most popular messenger application among the collage students (Jadhav, Bukhtar, and Mehta , 2013).

WhatsApp can be used in education for different purpose (Nirgude and Naik, 2016). It had researched that the application has potential to support the learning process and has implications for pedagogy, allowing direct access to many online sources, and student responsibility on their own learning (Gon and Rawekar, 2017). A learning process is mixed by combining class room activities with WhatsApp activiteis instead of conducting entire learning in the class for the course scientific research methods in information science and found very effective (Barhoumi, 2015)

As explained above, the author tried to enhance the student's responses through blended learning with WhatsApp application. Research questions are; how to use blended learning 
with WhatsApp application in course of Research Method? How students' response about implementation blended learning with WhatsApp application.

\section{Method}

This study was conducted at Department of Mathematics Education, Faculty of Mathematics and Natural Sciences, Medan State University. The Subject was students in Class B year 2016 Department of Mathematics Education in fifth semester. In accordance with the background of the problem, this research was held at course of Research Method with 39 students. The students use National Standard Qualification based curriculum. Students have studied prerequisite courses in previous semester, namely Statistical Methods and Evaluation of Learning Achivement. Each of students has WhatsApp Application on their own smart phone. The object of tihs study was students' respon in course of Research Method. Desciption of research stages appear in Table 1.

Table 1: Description of Research Stages

\begin{tabular}{|c|c|}
\hline Stage & Description \\
\hline Survey & $\begin{array}{l}\text { Determining problems of research. This stage aimed to } \\
\text { explore the perceptions of students about course of } \\
\text { Research Method in oder to get informations why } \\
\text { students need long time to compile research proposal. The } \\
\text { main cause was low students' responses. Next, } \\
\text { determining solutions to solve the cause of the problem } \\
\text { through literature review, namely blended learning with } \\
\text { WhatsApp Application. }\end{array}$ \\
\hline Collecting data & $\begin{array}{l}\text { At this stage, the authors implement blended learning on } \\
\text { the subject of research. Lectures are conducted } 2 \text { times } \\
\text { off-line and } 2 \text { times online. Lectures begin with offline } \\
\text { learning (class room learning) then online learning (use } \\
\text { whatsapp application) alternately. Data collection was } \\
\text { done through; observation (during offline and online } \\
\text { learning) and interviews outside lecture time. }\end{array}$ \\
\hline Analysis & $\begin{array}{l}\text { At this stage the author conducts an in-depth analysis of } \\
\text { the results of observations and interviews. }\end{array}$ \\
\hline
\end{tabular}

The instruments that used in this study were interview and observations. The interview was given to the research subject at the survey stage and the data collection stage was more particularly after 4 times of learning. Interview questions are structured so that they are not only to reveal students' difficulties in compiling research proposals but also to reveal students' response in the course of research method. The observations was held during the lecturer (both of face-to-face learning and on-line learning with WhatsApp Aplication). The main elements observed from students are; student learning preparation, student participation in asking questions, and student participation in giving opinions on other students' questions.

\section{Results And Discussion}


At the survey stage, author observed 10 students and interviewed the students and several thesis supervisors. From the survey stage, it was found that the factor that caused students took long time to compile research proposals were low student responses in course of research method. This course not only explains various concepts about research but also teaches methods and techniques for compiling chapters I to chapter III of research proposals. The course is accepted by students in the 6th semester meanwhile students began to prepare proposals at the beginning of 8th semester. In theory, low student responses to the course had an impact on students' low ability in compiling research proposals. After conducting a literature review, the authors chose blended learning in the hope that the implementation of blended learning can enhance student responses to the course of research method.

\section{Usage blended learning with WhatsApp application in course of Research Method}

The implementation and data collection stage was conducted in the odd semester of Academic year 2018/2019, precisely in the course of research method. The author began the preparation of the implementation of blended learning in the inaugural week in Medan State University, precisely when the course contract was explained. The author gave technical instructions on how to implement blended learning where in this study the lecture was held two times face-to-face learning in class room and two times learning with WhatsApp Application out of class room. Details of blended learning lectures are; preparation on $23^{\text {th }}$ August 2108, first face-to-face learning on $30^{\text {th }}$ August 2108, first learning with WhatsApp application on $6^{\text {th }}$ September 2108 , second face-to-face learning on $13^{\text {nd }}$ September 2108 , and second learning with WhatsApp application on $20^{\text {th }}$ September 2108 . Both of face-to-face learning and learning with WhatsApp application, lectures use group discussion methods, where students in groups directly ask the lecturer. students formed study groups where 39 students were divided into 7 groups (there are four groups of six members and three groups of five members). Students formed group WhatsApp where all students put their group number before their name, show at Figure 1. 


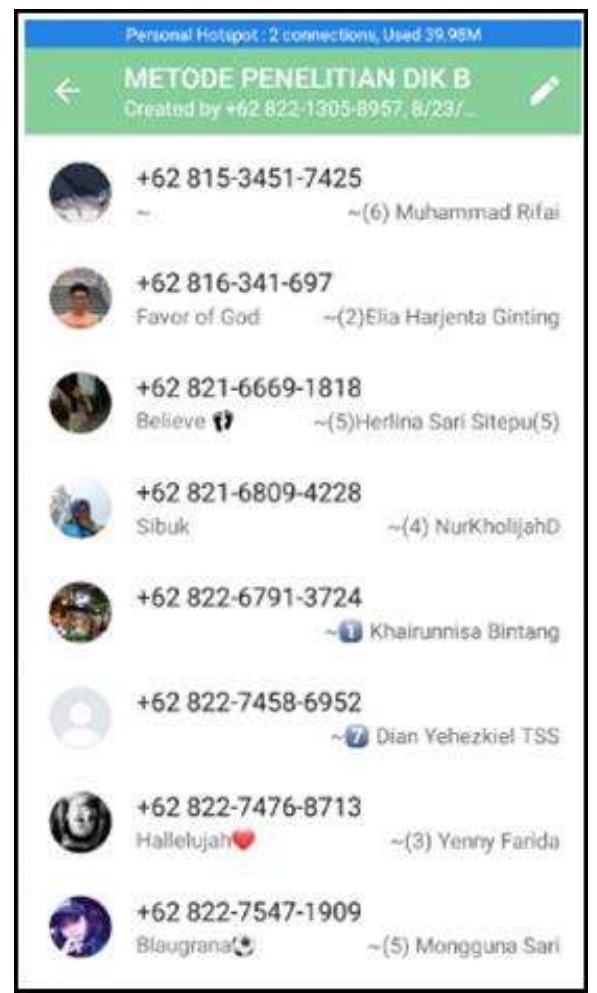

Fig. 1. Students put their group number before their name at WhatsApp application

Both of face-to-face learning and learning with WhatsApp application, the lecturer would be outlined the course material 3 days before the lecture schedule through social network. In addition, students are also required to have a research method book. Students must learn and develop the material that has been given by the lecturer so that in the lecture schedule students just ask about the material to be studied.

\section{Students' response about implementation blended learning with WhatsApp application.}

After the implementation of blended learning for four meetings, the author and the second author conducted depth interviews with all researchsubjects. Summary of students' answers from each question is presented below.

How is your preparation before learning? Students prepare carefully a day before learning in both of face-to-face learning and learning with WhatsApp application. Each student read several books related to the material that has been given to them. They tried to understand the same concept with different perspectives, even they tried to make examples in the field of mathematics education.

Did you understand all learning material? Students understand the learning material well. This was because they had been given out line material three days before the lecture so they focused on developing the material. 


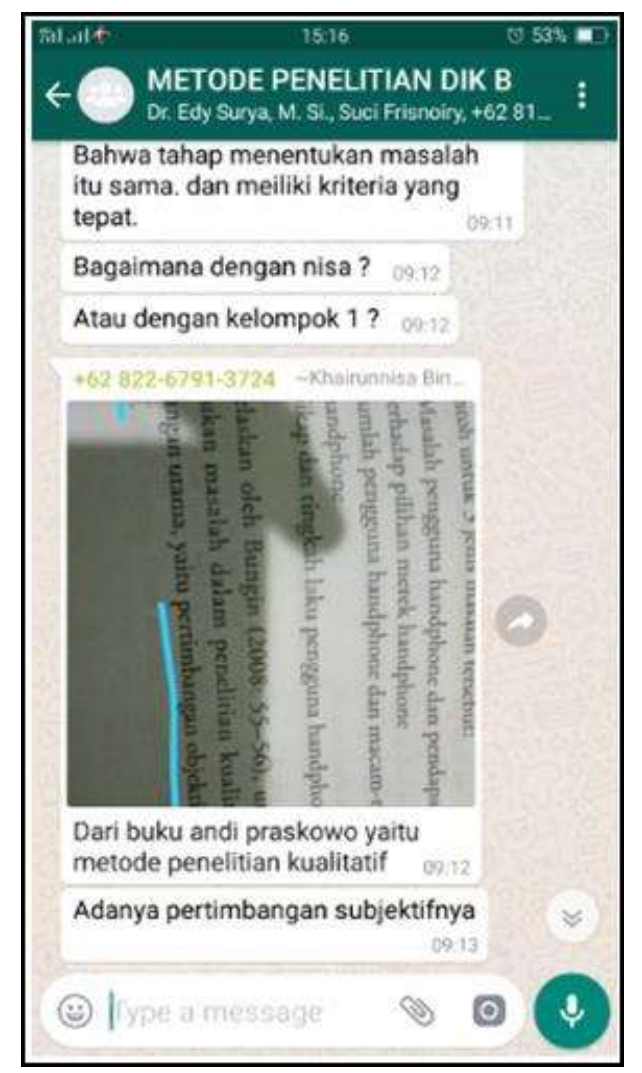

Fig. 2. Students took photos of their reading material to discussed through whatsApp application

What did you think about the implementation of blended learning? Students felt comfort and more flexible particularly learning with WhatsApp application. They can did discussion learning everywhere and in any condition. When learning through WhatsApp were conducted, students at home had more access to various reading materials than in classrooms where they can only brought limited reading material. They easily took photos of their reading material to discussed through whatsApp application, show at Figure 2. They don't even need to take a bath before began to study. The students feels confident that they will not forget the material and explanation of this course for many years because learning with WhatsApp application leaves a digital imprint on their smart phones so that it can be learned the next two or three years.

\section{Conclusions}

Blended learning can be used through the WhatsApp application with careful preparation. Usage of Blended learning with WhatssApp application can enhance studens' responses. 


\section{References}

[1] Barhoumi, C., The effectiviness of WhatsApp Mobile Learning Activities Guided by Activity Theory on Students' Knowledge Management. Contemporary Educational Technology. Vol 6 (3), 221-238. (2015).

[2] Gon, S., and Rawekar, A.,. Effectivity of E-Learning through WhatsApp As A Teaching Learning Tool. MVP Journal of Medical Sciences. Vol 4 (1). 19 - 25. (2017)

[3] Jadhav, D., Bukhtar, G., Mehta, V., Usability Evaluation of Messenger Applications for Android Phones Using Cognitive Walkthrough. (2013).

[4] Lestari, E. L.,. Implementasi Brain Based Learning untuk Meningkatkan Kemampuan Koneksi dan Kemampuan Berpikir Kritis Serta Motivasi Belajar Siswa. Jurnal Pendidikan Unsika. Vol 2 (1), 36-46(2014)

[5] Mohammed, S., Laila, E., Hamza, A., Mobile Learning (M-Learning) and Educational Environments. International Journal of Distributed and Parallel Systems. Vol 3(4), 31-38. (2012).

[6] Motlan, Sinulingga, K., Siagian, H.,. Inquiry and Blended Learning Based Learning Material Development for Improving Student Achievment on General Physics I of Mathematics and Natural Science of University State of Medan. 3rd Annual International Seminar on Trends in Science and Science Education. Unimed.(2016)

[7] Nirgude, M., Naik, A. WhatsApp Application: An Effective Tool for Out-of-Class Activity. Journal of Engineering Education Transformation, Special Issue(2016).

[8] Pierce, R., Stacey, K. Observation on Student's Responses to learning in CAS environment. Mathematics Education Research Journal.Vol 13 (1), 28-46

Singh, H., 2003. Building Effective Blended Learning Programmes. Issue of Educational Technology. (2001).

[9] Skinner, C. H., Increasing Learning Rates by Increasing Students response rates: A Summary Research. School Psychology Quarterly, Vol 11(4), 313-325. (1996).

[10] Yeboah, J., Ewur, G. D.,. The Impact of WhatsApp Messenger Usage on Students Performance in Tertiary Institutions in Ghana. Journal of Education and Practice. Vol 5 (6), 157 - 164. (2014) 